\title{
UMBATRA
}

Indonesian Journal of Anthropology

Volume 6 (2) Desember 2021 || eISSN 2528-1569

DOI : 10.24198/umbara.v6i2.35861

pISSN 2528-2115 || http://jurnal.unpad.ac.id/umbara

\section{Dominasi atau Kontestasi? : Relasi Negara dan Masyarakat di Desa Karangwuni di Masa Pandemi Covid-19}

\author{
Yayuk Windarti \\ Departemen Antropologi, Fakultas Ilmu Sosial dan Ilmu Politik, Universitas Indonesia \\ yayuk.windarti@ui.ac.id
}

\begin{abstract}
The Covid-19 pandemic, which has occurred in Indonesia since March 2020, has created a crisis in society. The state began to take appropriate policies in handling the Covid-19 pandemic. The alignment of state's policies in the economic or health sectors has been questioned. This research aims to examine the state's practices in delivering aid to members of society and the incoherent images about the state which results from the practice. The relationship between the state and the society was analyzed through Migdal's framework. This autoethnographic research was conducted in Karangwuni Village, Polokarto District, Sukoharjo Regency. Data were collected through participatory observations, archival study, and in-depth interviews with various members of social groups, such as village chief, midwives, and residents who are directly affected by Covid-19. The result of this research indicated that the village has become an arena for domination contests by the state and the society. The state's practice of delivering aid to members of society through the village government has led village authorities, health workers, and the aid beneficiaries to construct various images about the state. Apparently, the state is not the dominant actor. The image of the state that was originally coherent has been challenged as both the state and the society tend to pull out each other.
\end{abstract}

Keywords: relation, contestation, domination, assistance, village

\begin{abstract}
Abstrak
Pandemi Covid-19 yang terjadi di Indonesia sejak Maret 2020 menciptakan krisis di masyarakat. Negara pun dituntut mengambil kebijakan yang tepat untuk menangani pandemi Covid-19. Keberpihakan kebijakan negara pada sektor ekonomi atau kesehatan pun dipertanyakan. Penelitian ini bertujuan melihat praktik pemberian bantuan dari negara pada masyarakat dan berbagai image negara yang tidak koheren dalam masyarakat. Relasi antara negara dan masyarakat dianalisis melalui kerangka Migdal terkait state in society. Penelitian autoetnografi ini dilakukan di Desa Karangwuni, Kecamatan Polokarto, Kabupaten Sukoharjo. Pengumpulan data dilakukan dengan observasi partisipasi, studi dokumentasi, dan wawancara mendalam dengan berbagai perwakilan warga masyarakat setempat terutama yang terdampak Covid-19. Hasil penelitian menunjukkan bahwa praktik pemberian bantuan negara melalui pemerintah desa di Desa
\end{abstract}


Karangwuni menjadi arena kontestasi dominasi, baik oleh negara maupun oleh masyarakat. Praktik pemberian bantuan menampilkan keberagaman image negara di mata aneka kelompok masyarakat, di antaranya para birokrat, tenaga kesehatan, dan masyarakat terdampak. Dengan kata lain, negara bukanlah satu-satunya agen yang mendominasi. Melalui praktik, image negara yang mulanya koheren pun digugat. Relasi negara dan masyarakat menggambarkan relasi tarik-menarik satu sama lain.

Kata kunci: relasi, kontestasi, dominasi, bantuan, desa

\section{Pendahuluan}

Pandemi Covid-19 telah terbukti menciptakan krisis di berbagai tempat dan sektor dalam masyarakat. Virus tersebut telah menginfeksi jutaan jiwa manusia dan tidak sedikit yang berujung kematian. Kasus pertama Covid 19 di Indonesia terkonfirmasi pada tanggal 2 Maret 2020 (Harirah dan Rizaldi, 2020). Sejak saat itu, negara mengemban tugas melindungi masyarakat dengan menekan penyebaran virus Covid-19. Berbagai langkah ditempuh pemerintah, di antaranya menganjurkan masyarakat menerapkan social distancing (pembatasan sosial) dan physical distancing (pembatasan fisik) (Mulyadi, 2020). Selain itu pemerintah juga menyalurkan bantuan finansial dan pangan pada masyarakat terdampak pandemi, termasuk masyarakat desa.

Pada masa awal merebaknya Covid-19, perdebatan panas pun mengemuka di masyarakat mengenai keberpihakan pemerintah; apakah pemerintah seharusnya berpihak pada sektor kesehatan atau sektor ekonomi. Hal ini juga menjadi dilema besar bagi pemerintah. Kebijakan lockdown di negara lain untuk memutus rantai penularan virus, sulit dilakukan pemerintah Indonesia. Kebijakan ini, jika diterapkan, akan berakibat pada lemahnya sektor ekonomi karena semua aktivitas harus dilakukan di rumah. Sebaliknya, bila lockdown tidak diterapkan, maka penyebaran Covid-19 pun semakin sulit dihentikan. Kebijakan lockdown atau tidak, menjadi wacana pro dan kontra di berbagai kalangan. Pemerintah akhirnya menerapkan kebijakan pembatasan mobilitas yang diikuti dengan penyaluran bantuan sosial. Kebijakan ini menggambarkan relasi antara negara dengan masyarakatnya di masa pandemi.
Penelitian terdahulu tentang relasi negara dan masyarakat, antara lain penelitian Therik (2015), yaitu tentang relasi negara dan masyarakat di Kepulauan Rote. Therik menggunakan konsep civil society untuk menjelaskan peran Nusak atau lembaga peradilan adat masyarakat Rote yang digunakan masyarakat ketika berhadapan dengan negara. Ia menolak anggapan bahwa negara dan masyarakat adalah dua entitas yang saling memengaruhi satu sama lain. Therik melihat ada pihak yang dominan dalam relasi di antara negara dan masyarakat untuk mewujudkan demokrasi.

Penelitian Kerkvliet (2018) yang berjudul "An Approach for Analysing State-Society Relations in Vietnam" menunjukkan beragam interpretasi mengenai relasi negara dan masyarakat. Fokus penelitian Kerkvliet terbilang kompleks karena menyoroti institusi negara, media massa, pertanian kolektif, dan korupsi. Negara tampak sebagai pihak dominan; saat media massa berada di bawah kontrol negara. Di sisi lain, terdapat interpretasi dialogis yang menilai bahwa masyarakat juga mampu memengaruhi kebijakan negara. Penelitian Therik (2015) dan Kerkvliet (2018) menjadi landasan bagi penelitian ini untuk menyoroti relasi negara dan masyarakat dalam tataran mikro dengan mengambil contoh kasus penanganan krisis pandemi di wilayah pedesaan oleh negara.

\section{Kajian Pustaka}

Weber dalam Migdal (2004) menjelaskan bahwa negara secara konseptual hadir sebagai organisasi otonom yang mampu mendominasi. Berdasarkan kacamata Weber, negara hanya akan hadir ketika terdapat rasionalitas, profesional, maupun birokrat. Oleh karena itu, 
di dalam konteks pandemi, tidak salah jika pemerintah memiliki dominasi untuk menentukan kebijakan dan bantuan yang dinilai tepat dalam penanganan Covid-19.

Presiden Jokowi disebut lebih berpihak pada sektor ekonomi saat mengabaikan opsi lockdown yang sebenarnya telah diatur dalam Undang-Undang Karantina Kesehatan tahun 2018. Selain itu, presiden juga disebut lebih mempercayakan penanganan virus Covid-19 pada militer dibanding profesional kesehatan masyarakat. Fenomena ini menggambarkan konsep Weber bahwa negara sebagai satu-satunya organisasi yang legal untuk menciptakan rasa takut di kalangan masyarakat agar patuh pada aturan yang telah disusun. Image negara sebagai agen yang demikian pun terus direkonstruksi dan dipertahankan; meski, pada praktiknya, tidak sedikit kepala daerah maupun aktor masyarakat yang justru memunggungi kebijakan negara. Misal, saat Ganjar Pranowo selaku gubernur Jawa Tengah menegaskan perlunya mengutamakan kesehatan masyarakat agar perekonomian dapat tetap berjalan. Ketika ekonomi yang diprioritaskan, maka banyak masyarakat yang akan mati. Pernyataan Ganjar secara implisit justru mendukung kebijakan lockdown (Bayuni, 2020).

Pemerintah akhirnya menerapkan kebijakan PSBB (Pembatasan Sosial Berskala Besar) alih-alih lockdown. PSBB diartikan sebagai tindakan pembatasan kegiatan bagi penduduk dalam suatu wilayah yang dianggap sebagai zona merah atau wilayah yang memiliki kasus Covid-19 tinggi agar penyebaran Covid-19 dapat ditekan (Saraswati, 2020). Penerapan PSBB meliputi peliburan sekolah dan tempat kerja, pembatasan kegiatan keagamaan, dan/ atau pembatasan kegiatan di tempat atau fasilitas umum (Karyono, Rohadin, dan Indriyani, 2020).

Mengikuti penerapan PSBB, pemerintah menyusun berbagai program bantuan, baik dalam bentuk finansial maupun emosional. Di wilayah pedesaan, penyaluran bantuan dilakukan oleh perangkat desa. Interaksi antara perangkat desa dengan masyarakat dalam kegiatan menyalurkan bantuan pemerintah dapat dilihat sebagai bentuk relasi negara dengan masyarakat dalam praktik yang nyata.

Joel S. Migdal (2004) dalam "State in Society" menyebut bahwa negara bukan satu-satunya agen yang mampu menciptakan aturan bagi masyarakat. Lagi pula, ketika aturan tersebut dipraktikkan, tidak menutup kemungkinan banyak terjadi pelanggaran yang kontras dengan image koheren negara. Negara dibentuk melalui dua elemen, yaitu image dan praktik. Meminjam konsep image dari Shils, image tentang negara merupakan gabungan dari $i$ mage institusi. Namun, Migdal tidak berhenti pada konstruksi image. Ia menyoroti praktik di dalam masyarakat. Berangkat dari praktik yang ada, dapat dilihat bagaimana batas-batas teritorial dan sosial yang mulanya jelas menjadi kabur. Namun, ada ruang-ruang tertentu di masyarakat yang tidak dapat disentuh oleh negara. Aturan dan norma yang sering kali berbentuk koheren sebenarnya ditentukan oleh banyak orang. Aturan yang dipraktikkan bukannya hadir tanpa kontestasi. Negara bukanlah satu-satunya pihak dominan dalam masyarakat. Relasi negara dan masyarakat adalah relasi tarik-menarik satu sama lain (Migdal, 2004).

Gagasan Migdal menjadi kacamata dalam penelitian ini untuk melihat relasi negara dengan masyarakat melalui image dan praktik. Penggunaan konsep Migdal sebagai pisau analisis didasarkan pada arena penelitian yang tidak hanya berfokus pada program pemerintah sebagai aspek konseptual, tetapi juga pengaplikasiannya dalam masyarakat. Kompleksitas relasi antara negara dan masyarakat dapat dilihat melalui praktiknya. Penelitian ini menyajikan upaya masyarakat Desa Karangwuni menangani Covid-19 sebagai bentuk keberagaman image negara dalam satu tubuh masyarakat, dan menggambarkan relasi negara dengan masyarakat yang terbentuk lewat keterkaitan antara image dan praktik.

\section{Metode}

Penelitian ini dilakukan di Desa Karangwuni, 
Kecamatan Polokarto, Kabupaten Sukoharjo, Jawa Tengah. Desa ini dipilih sebagai lokasi penelitian karena menjalankan praktik penanganan Covid-19 yang kontras dengan skenario negara dalam menangani Covid-19. Dengan kata lain, desa ini merupakan arena aktual di mana pemerintah pusat, pemerintah daerah, dan masyarakat, saling bergesekan memperebutkan kekuasaan.

Penelitian ini menggunakan metode autoetnografi. Penulis merupakan warga desa Karangwuni. Di dalam penelitian ini, penulis menerapkan prinsip autoetnografi, di mana peneliti menjadi insider sekaligus outsider yang dalam prosesnya bersifat dialogis $(\mathrm{Bu}-$ zard, 2003). Metode ini memungkinkan peneliti menangkap berbagai representasi yang muncul dari berbagai lapisan masyarakat Desa Karangwuni. Teknik pengumpulan data dalam penelitian ini dilakukan dengan cara observasi partisipasi, wawancara mendalam, dan dokumentasi. Penulis turut berpartisipasi dalam beberapa kegiatan yang menyokong pemberian bantuan pada masyarakat. Misal, membantu menyediakan bantuan di papan cantel sedekah serta membantu ibu-ibu memasak guna menyuplai masyarakat terdampak Covid-19 serta masyarakat yang berjaga selama proses tersebut.

Informan penelitian meliputi kepala desa, bidan desa, dan beberapa perwakilan warga masyarakat setempat. Kepala desa dipilih sebagai informan berdasarkan perannya sebagai pilot dalam pengorganisasian program pemerintah dalam penanganan Covid-19 di tingkat desa. Bidan desa dipilih sebagai informan karena merupakan garda terdepan yang menangani masyarakat yang terkonfirmasi terjangkit virus. Perwakilan warga masyarakat dipilih sebagai informan karena posisinya sebagai sasaran program pemerintah. Prosedur pemilihan informan ini juga mempertimbangkan kekayaan perspektif, yaitu dari golongan elit dan masyarakat umum. Selain itu, keberagaman perspektif ini juga diupayakan untuk meminimalisasi bias dan memperkuat validitas data.

Analisis data dalam penelitian ini dilakukan dengan mengikuti prinsip Creswell (2007) yaitu: pertama, mengorganisir data yang telah dikumpulkan dalam berkas manual maupun berkas digital (berupa rekaman suara dan foto). Pada tahap ini, data yang diperoleh dikonversikan ke dalam bentuk kalimat langsung dan kalimat tidak langsung. Tahap kedua yaitu membaca ulang transkip wawancara dan data yang sudah diorganisir. Hal ini dilakukan untuk memperoleh detail selama di lapangan. Selain itu, catatan yang terdiri dari frasa pendek, gagasan penting dan menarik, serta kata kunci juga dibuat. Tahap ketiga yaitu proses deskripsi, klasifikasi, dan interpretasi. Data-data yang sudah dikumpulkan dideskripsikan dan diberikan pemaknaan berdasarkan setiap fenomena yang diamati ketika penelitian berlangsung.

\section{Hasil dan Pembahasan}

\section{Solidaritas untuk Stabilitas Desa}

Desa Karangwuni terletak di Kecamatan Polokarto, Kabupaten Sukoharjo, Jawa Tengah. Desa ini terdiri atas tiga dusun kecil. Masyarakat desa ini mayoritas beragama Islam dan memiliki latar belakang perekonomian dan kelas sosial yang beragam. Desa ini merupakan salah satu bagian dari jalur "jalan ciu". Sebab, mayoritas masyarakat di desa, menggeluti usaha ciu atau etanol, selain bekerja di sektor pertanian.

Ciri khas kehidupan desa, seperti gotong-royong dan solidaritas masih terasa kental di desa ini. Para ibu masih antusias mengikuti rewang untuk membantu tetangga yang menggelar hajatan. ${ }^{1}$ Para bapak juga masih menyempatkan waktu untuk mengikuti gugur gunung atau gotong-royong membersihkan desa. Anakanak muda masih kerap berkumpul dan me-

\footnotetext{
${ }^{1}$ Di dalam kegiatan rewang, biasanya ibu-ibu bertugas untuk menyiapkan makanan bagi tamu hajatan. Mereka secara kolektif membagi tugas untuk memasak, menyiapkan, dan menyajikan makanan. Rewang menjadi kegiatan sosial di desa. Apabila ada anggota ibu-ibu yang tidak pernah bergabung dalam rewang, maka akan memperoleh sanksi sosial berupa pengucilan maupun menjadi bahan pergunjingan.
} 
nyalurkan kreativitas mereka dengan menyelenggarakan acara yang dapat dinikmati oleh masyarakat setempat. Nilai-nilai solidaritas tersebut masih dipupuk hingga saat ini. Nilai solidaritas ini pula yang menjadi tameng masyarakat Karangwuni dalam menghadapi Covid-19. Hal ini sejalan dengan konsep "social system" yang dikemukakan Talcott Parson dikutip Migdal (2004) bahwa inti dalam masyarakat adalah sebuah perintah normatif yang terpolakan melalui kehidupan populasi yang terorganisir secara kolektif. Tidak ada masyarakat yang dapat menjaga stabilitas dalam menghadapi berbagai tekanan kecuali memperhatikan konstelasi kepentingan anggotanya yang didasarkan pada solidaritas dan internalisasi loyalitas dan kewajiban.

\section{Desa sebagai Arena Kontestasi Dominasi}

Negara mengeluarkan kebijakan agar setiap daerah patuh pada anjuran dan tidak mengambil kebijakan sendiri dengan menerapkan lockdown. Presiden Jokowi, dalam sebuah konferensi pers, menegaskan bahwa pemerintah daerah tidak boleh menerapkan kebijakan sendiri-sendiri di wilayahnya yang tidak sesuai dengan protokol pemerintah pusat (Ristyawati, 2020). Selain itu, ada aturan dalam UU No. 6 Tahun 2018 yang menyatakan bahwa pemerintah pusat yang memiliki wewenang untuk mengeluarkan suatu kebijakan kedaruratan kesehatan (Aziz et al., 2021). Pemerintah mempunyai alat untuk menciptakan tertib sosial dalam bentuk hukum dan kebijakan yang nantinya digunakan sebagai kontrol sosial (Ekklesia, 2021). Dengan kata lain, negara boleh saja membangun image sebagai entitas yang dominan, tetap, dan utuh, seperti yang digambarkan oleh Weber. Namun, praktik di lapangan tidak dapat diabaikan. Respon kelompok maupun aktor masyarakat terhadap suatu kebijakan tidak dapat diprediksi. Sama seperti yang disampaikan Migdal dalam State in Society (2004) bahwa masyarakat bukanlah objek pasif, melainkan sebagai subjek aktif dalam menjalankan aturan yang digagas oleh negara. Pada akhirnya, negara pun memiliki keterbatasan di balik citranya yang utuh.
Penanganan Covid-19 di Desa Karangwuni bertentangan dengan kebijakan pemerintah pusat. Hal ini tampak dari penerapan lockdown di Desa Karangwuni dan sekitarnya yang bertentangan dengan instruksi presiden. Pada bulan-bulan puasa dan lebaran, desa ini dijaga ketat oleh masyarakat. Mereka bahkan membangun pos keamanan yang terbuat dari kumpulan bambu yang dibentuk sedemikian rupa dan diletakkan mematang jalan layaknya sebuah portal. Bambu itulah yang menjadi batas siapa-siapa saja yang boleh memasuki desa. Pada masa yang menegangkan tersebut, masyarakat desa dengan inisiatifnya sendiri memperjelas batas teritorialnya. Batas ini yang memperjelas subjek masyarakat sebagai insiders atau outsiders. Hal ini sekaligus menunjukkan bahwa batas teritorial dapat bervariasi dan makna yang melekat pada batas-batas citra negara pun dapat ditantang dengan berbagai cara.

Masyarakat membentuk aturan-aturan sendiri, misalnya dalam hal pembagian kerja. Di dalam hal ini, bapak-bapak dan pemuda secara berkelompok bertugas untuk menjaga pos dan melakukan ronda malam. Ayah saya bahkan mendapat selebaran yang berisikan jadwal untuk jaga pos semalam suntuk. Ketika berjaga, mereka dibekali dengan termometer pengecek suhu tubuh, keran cuci tangan buatan yang sebelumnya sudah dibuat oleh kepala desa beserta perangkatnya, dan sabun cuci tangan. Mereka memegang kontrol terkait akses keluar masuk desa. Orang asing maupun saudara jauh yang ingin sekadar berkunjung ke rumah salah seorang warga desa, mereka harus melewati proses seleksi terlebih dahulu. Individu dengan suhu di atas $37,5^{\circ} \mathrm{C}$ tidak diperbolehkan masuk dan setiap orang diwajibkan untuk memakai masker. Hal-hal inilah yang kita sebut sebagai sistem "new normal", yaitu kondisi berbagai regulasi pencegahan virus perlahan melekat pada perilaku keseharian masyarakat.

Selain itu, masyarakat juga membuat regulasi sendiri terkait mekanisme bagi pemudik yang ingin kembali ke desa. Mengingat sekolah diliburkan, pemerintah desa menjadikan sekolah 
TK (Taman Kanak-Kanak) sebagai tempat isolasi bagi para pemudik. Di sana, kepala desa sudah menugaskan hansip untuk berjaga untuk mencegah pemudik melarikan diri dari isolasi. Isolasi normalnya dilakukan dalam kurun waktu 10 hingga 14 hari. Di sana, pemudik sudah disediakan berbagai fasilitas maupun pemenuhan kebutuhan sehari-hari serta memperoleh pengecekan rutin dari bidan desa. Kebutuhan sehari-hari pemudik yang diisolasi telah dicukupi dari hasil masakan ibu-ibu yang memiliki jadwal masak seperti halnya jadwal ronda bapak-bapak. Ibu-ibu secara bergantian mengemban tugas untuk menyediakan minuman hangat dan makanan yang diberikan kepada bapak-bapak yang berjadwal menjaga pos serta kepada pemudik yang diisolasi.

Bagi masyarakat yang terpaksa diisolasi mandiri karena terinfeksi, mereka secara otomatis tidak dapat keluar rumah, sekalipun untuk mencukupi kebutuhan sehari-hari. Pemerintah desa pun memberikan bantuan berupa sembako dan membentuk mekanisme "Jaga Tangga" dengan menggerakkan tetangga terdekat untuk merawat yang terinfeksi. Di dalam hal ini, merawat tetangga berarti menyuplai kebutuhan pokok sehari-hari, seperti makanan, obat-obatan, pembalut, dan lain sebagainya.

Pada suatu ketika, terdapat salah satu anggota keluarga yang dinyatakan positif Covid-19. Pada saat itu, ibu-ibu PKK inti langsung berkumpul di rumah ibu lurah, dengan menggunakan masker dan menjaga jarak untuk mengoordinasi perawatan anggota masyarakat yang terinfeksi. Mereka duduk melingkar di atas tikar dengan suasana hening, mungkin karena mereka kaget. Selanjutnya, mereka membentuk jadwal khusus untuk mengurus keluarga yang diisolasi secara bergantian dan pertemuan pun berakhir dengan singkat. Deskripsi tersebut sejalan dengan cara Shils dalam Migdal (2004) menggambarkan bahwa pada dasarnya masyarakat tidak hanya terikat melalui hubungan material dan instrumental. Selanjutnya, Migdal (2004) menjelaskan bahwa hubungan antara satu dengan yang lain terletak pada gagasan tran- sendental di mana mereka mencari dan menciptakan pemahaman atau makna bersama yang kuat dalam hubungan mereka, serta membentuk perekat relasional yang kuat yang mengikat mereka bersama. Migdal pun mengagumi gagasan Shils dan berpikir bahwa hubungan sosial telah melampaui aspek kognitif menuju afektif dan bahkan melampaui dimensi instrumental menuju emosional.

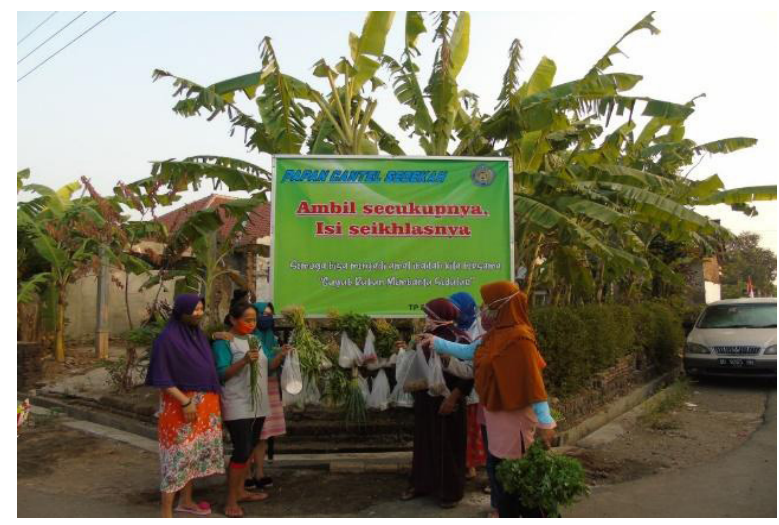

Gambar 1. Papan Cantel Sedekah: Ibu-ibu sedang menaruh sayur-sayuran yang dibeli di pasar untuk nantinya diambil masyarakat yang membutuhkan. Sumber: dokumentasi peneliti

Gambar 1 menunjukkan bahwa baik masyarakat dan birokrat desa memiliki kekuatan mendominasi arena mereka dan menyebarkan dominasi itu. Selain itu, gambar di atas juga merupakan wujud nyata solidaritas dan rasa saling percaya antarmasyarakat yang dipupuk di tengah kesulitan ekonomi. Nilai-nilai kebudayaan lokal dapat dijadikan sebuah kekuatan atau dasar moral untuk mengakomodasi perasaan kolektif masyarakat untuk mencapai sebuah solidaritas di tengah masa pandemi saat ini (Funay, 2020). Masyarakat Desa Karangwuni saling menyuplai kebutuhan dapur bagi yang membutuhkan di sebuah "Papan Cantel Sedekah". Mereka dapat menggantungkan dan mengambil sayuran, bumbu dapur, maupun buah-buahan tanpa dipungut biaya.

Tentu saja tidak semua desa menerapkan regulasi semacam ini. Sebagian desa membebaskan akses keluar masuk wilayah dan ada pula yang melakukan penjagaan yang lebih ketat dengan cara yang beragam. Di sini dapat dilihat bagaimana pemerintah desa telah berani 
mengambil langkah dengan mencoba memanfaatkan desa sebagai arena untuk mendominasi dan memanfaatkan sumber daya wilayah sekalipun cukup bertentangan dengan negara. Namun, hal ini menjadi gambaran bagaimana negara sendiri kemudian didasarkan pada sistem patronase di mana para pemegang otoritas tingkat lokal lainnya menjalankan kebijakan yang luar biasa di arena lokal.

Deskripsi di atas menunjukkan apa yang ditekankan Migdal (2004) sebagai proses yang menentukan cara aturan dan pola dominasi serta subordinasi ditantang dan diubah. Proses penanganan Covid-19 oleh birokrat desa dan masyarakat di atas yang menentukan bagaimana negara dan masyarakat menciptakan dan memelihara cara-cara yang berbeda untuk menata ulang kehidupan sehari-hari yang terdampak oleh Covid-19. Proses ini pula yang mengatur cara berperilaku dan mengidentifikasi elemen yang menguntungkan maupun merugikan bagi masyarakat Desa Karangwuni. Hal ini menunjukkan bahwa tidak ada seperangkat nilai yang terintegrasi di manapun.

Cara penanganan masyarakat Desa Karangwuni memperkuat gagasan bahwa tidak ada dominasi penuh dari negara, dapat dilihat dari cara mereka bergotong-royong membangun stabilitas sebagai representasi bahwa nilai dan norma pada dasarnya memang ditentukan oleh banyak orang. Aturan yang diterapkan pemerintah bukannya diterima secara pasif oleh masyarakat. Mereka yang sadar akan kebutuhan dan kapasitasnya sendiri secara aktif berkontestasi dengan kebijakan negara. Partisipasi masyarakat untuk aktif berperan merupakan unsur social control. Mereka memberikan kontibusi peran, sebanding dengan peran negara sebagai government control (Pribadi, 2020). Mau tidak mau, harus diakui bahwa memang ada ruang-ruang tertentu yang tidak dapat disentuh oleh negara. Image negara yang koheren pun harus dipertanyakan kembali. Oleh karena itu, selanjutnya akan digambarkan keberagaman image negara dalam satu tubuh masyarakat Desa Karangwuni lewat pemberi-

\footnotetext{
${ }^{2}$ Ora oleh sembako berarti tidak mendapat sembako.
}

an bantuan dari pemerintah.

\section{Ora Oleh Sembako! ${ }^{2}$ Menentang Image Ko- heren Negara}

Pemerintah desa berperan sebagai lini paling bawah yang berinteraksi langsung dengan masyarakat. Migdal telah mengidentifikasi empat tingkat organisasi negara, dari bawah ke atas, sebagai the trenches, the dispersed field offices, the agency's central offices, and the commanding heights (Migdal, 2004). Pemerintah desa pun masuk dalam kategori the trenches di mana mereka harus melakukan pertempuran sehari-hari dengan kekuatan sosial lainnya. Mereka juga harus melaksanakan arahan negara sekaligus menghadapi kemungkinan perlawanan masyarakat. Tekanan pun datang tidak hanya dari pengawasan atasan, tetapi juga langsung dari masyarakat yang dituju dan dari tokoh-tokoh tingkat rendah di organisasi sosial besar lainnya.

Peran pemerintah desa dalam mengendalikan masyarakat beserta sumber dayanya untuk menciptakan stabilitas wilayah sangat besar. Akumulasi perjuangan dan dominasi oleh pemerintah desa pun berpeluang untuk menggerakkan masyarakat maupun sebaliknya, yaitu menciptakan konflik. Di dalam menggambarkan dinamika akibat dominasi ini, dapat dianalisis melalui penyaluran bantuan oleh pemerintah desa pada masyarakat. Sebelum menunjukkan keberagaman hasil dominasi oleh pemerintah Desa Karangwuni, saya ingin menunjukkan perspektif pemerintah desa dalam menyalurkan bantuan sebagai upaya penanganan dampak Covid-19.

Pak Hartono adalah lurah Desa Karangwuni. Ia masih berusia muda, sekitar 35 tahun. Pendidikannya terbilang kurang cemerlang, tetapi latar belakangnya sebagai pengusaha (dengan banyak mitra dan klien) telah membantunya berada dalam posisi sekarang ini. Ia disegani sebagai pengusaha dan kepala desa muda yang sukses dan dikenal dermawan. Hal ini tergambar dari caranya menyumbangkan seluruh hasil pengolahan jatah sawah maupun tanah 
bengkok yang diwariskan pada setiap kepala desa secara turun-temurun untuk perkembangan masyarakat desa.

Kami pun mengobrol cukup banyak terutama terkait penanganan Covid-19 dan bantuan yang telah diberikan pemerintah desa pada masyarakat terdampak Covid-19. Sebenarnya pemerintah desa yang bertanggung jawab untuk mengoordinasi bantuan ini adalah KesiKesra (Kepala Seksi Kesejahteraan Sosial Masyarakat). Namun, dalam menyalurkan bantuan, pemerintah desa banyak meminta bantuan dari setiap kepala RT dan kepala RW di Desa Karangwuni.

Beberapa bantuan yang diberikan kepada masyarakat terdampak Covid-19, di antaranya ialah BST (Bantuan Sosial Tunai) dan BLT (Bantuan Langsung Tunai). Bantuan lain yang juga diberikan oleh pemerintah desa, yaitu JPSD (Jaringan Pengaman Sosial Daerah) dan DTKS (Data Terpadu Kesejahteraan Sosial). Sasaran dari bantuan ini adalah masyarakat yang kurang mampu atau miskin. Standar kurang mampu yang ditetapkan dengan pertimbangan kualitas rumah, jumlah pendapatan, maupun jenis pekerjaan. Namun sayangnya, pemberian bantuan didasarkan pendataan yang telah dilakukan sejak tahun 2015 yang artinya hingga saat ini belum ada pembaharuan data. Di sisi lain, bagi masyarakat yang membutuhkan bantuan biasanya harus menyiapkan berkas administratif berupa fotokopi Kartu Keluarga dan KTP. Mereka tidak meminta slip gaji mengingat mayoritas sasaran penerima bantuan adalah masyarakat yang bekerja sebagai petani maupun buruh.

Penerima bantuan DTKS sendiri digolongkan menjadi dua, yaitu PKH (Program Keluarga Harapan) dan BPNT (Bantuan Pangan Non Tunai). Penerima bantuan PKH disasarkan pada ibu hamil (yang miskin), anak-anak SD hingga SMA, lansia, dan penyandang disabilitas. Bentuk bantuan yang diberikan ialah uang tunai, sedangkan untuk jumlahnya Pak Hartono tidak ingat sebab bantuan biasanya langsung dikirim ke E-Warung atau ATM masing-masing. Penerima BPNT juga ter- golong orang yang kurang mampu. Bentuk bantuannya berupa sembako yang telah dibelanjakan dari uang sekitar Rp200.000,00. Sisanya ada pula bantuan berupa KIS. Mengingat banyaknya bentuk bantuan yang diberikan pada masyarakat, perlu ditegaskan bahwa setiap masyarakat hanya bisa menerima satu jenis bantuan.

Seperti yang bisa dilihat bahwa standar-standar mapan dan kurang mampu maupun miskin telah ditetapkan agar masyarakat menyadari bahwa negara itu "hadir" dalam setiap sudut kehidupan mereka. Gagasan ini disebutkan oleh Scott (1998) dalam bukunya yang berjudul "Seeing Like a State". Ia menggambarkan bagaimana negara berusaha membaca dan mengatur suatu masyarakat yang tidak berada dalam template yang dirancang oleh negara. Di dalam hal ini, negara pun berusaha untuk mempertahankan dominasinya dan menegaskan kehadirannya di saat masyarakat Desa Karangwuni mengalami krisis.

Pak Hartono sendiri menyampaikan bahwa bantuan yang diberikan pada masyarakat sudah merata bahkan terbilang berlebih. Sisa bantuan pun disalurkan kepada masyarakat yang belum menerima bantuan terlepas dari keadaan ekonominya yang mapan maupun tidak mapan. Hal ini karena Pak Hartono merasa bahwa seluruh masyarakat sebenarnya terdampak Covid-19 dalam aspek ekonomi. Namun, saya melihat bahwa dalam memberi bantuan pun Pak Hartono masih dipengaruhi oleh intersubjektivitasnya. Sebelumnya telah disinggung oleh Laszczkowski (2015) bahwa hubungan relasional tidak dapat dihindari dalam praktik bernegara. Meskipun Pak Hartono mengatakan bahwa semua masyarakat mendapat bantuan, ada pula keluarga yang tidak disalurkan bantuan, yaitu keluarga mertuanya (yang kebetulan tinggal sedesa). Hal ini berkaitan dengan pembentukan citra kemapanannya (beserta keluarga besarnya) sebagai kepala desa. Sekalipun keluarga mertuanya bermatapencaharian sebagai petani dengan penghasilan tidak tetap, ia mengasumsikan bahwa keluarga mertuanya tersebut "mapan". Di dalam mendefinisikan pengukuran standar 
mapan tersebut, sifatnya bisa jadi oleh Scott (1998) disebut dengan sticky atau lengket karena terus diperbaharui dan dimanipulasi. Berdasarkan fenomena ini, dapat dikatakan pula bahwa setiap perilaku pengukuran adalah perilaku yang ditandai oleh permainan relasi kekuasaan.

Namun terlepas dari hal itu, apabila diperhatikan bantuan yang diberikan pemerintah jenisnya sangat banyak dan beragam. Ada juga yang beranggapan bahwa bantuan tidaklah menggiring masyarakat pada kemandirian. Beragam respon bantuan semakin menggambarkan pluralnya pola pikir masyarakat. Sekali lagi, kita tidak dapat memprediksi reaksi masyarakat dalam menerapkan suatu kebijakan. Hal ini pun juga terjadi pada masyarakat Desa Karangwuni.

Pak Hartono mengakui bahwa akibat dari banyaknya bantuan yang disalurkan pada masyarakat adalah munculnya rasa kaget, cemas, dan cemburu, terutama pada awal saat bantuan diberikan. Hal ini karena mereka takut tidak mendapatkan bantuan. Mereka pun mulai membandingkan diri antara satu dengan yang lain terkait dengan siapa yang sudah dapat bantuan, bagaimana karakteristik ekonomi keluarga penerima bantuan, jenis bantuan, serta waktu penerimaan bantuan.

Ada anggapan yang muncul bahwa hanya orang yang kurang mampu saja yang layak menerima bantuan dari pemerintah. Sejauh ini dalam praktiknya, tidak banyak masyarakat yang melakukan manipulasi demi mendapatkan bantuan. Hal ini mungkin terjadi karena mengingat pemberian bantuan ini dilakukan di lingkup desa dan mereka saling mengenal satu sama lain sehingga paham betul bagaimana karakteristik masyarakatnya. Hanya saja ada masyarakat yang tidak bersabar dan mengekspresikan kekesalannya karena belum juga menerima bantuan pada waktu itu.

Mengingat ada pembatasan sosial, masyarakat mampu memanfaatkan media sosial untuk berkomunikasi tanpa harus bertatap muka maupun berinteraksi satu sama lain. Bebe- rapa kelompok masyarakat memiliki grup di aplikasi Whatsapp, salah satunya ialah grup bapak-bapak RT 02/RW 01, Dusun Baturan, Karangwuni. Di dalam grup tersebut, salah seorang bapak-bapak melakukan protes karena tidak kunjung menerima bantuan. Dursa (nama samaran) mengekspresikan kemarahannya, sebagai berikut:

“ $D *$ ncuk tenan ora oleh sembako. Sabar wes ora ono. Tonggone oleh opo gor Kon nyawang. Aku mundur dari jaga malam!" (Sialan benar belum memperoleh sembako. Sudah tidak bisa bersabar. Apabila tetangga mendapat (bantuan) apa ya cuma disuruh melihat). (Dursa, percakapan di grup Whatsapp, 28 April 2020)

Perlawanan dari masyarakat ini terjadi karena pemerintah desa tidak dapat sepenuhnya mengatur perilaku masyarakat. Pak Hartono pun berupaya untuk menenangkan warganya sebab timeline pemberian bantuan sepenuhnya bergantung pada pemerintah pusat. Pemerintah desa sebagai the trenches hanya bertugas untuk menyalurkan bantuan dari pemerintah pusat. Bantuan memang diberikan secara bertahap, dan pada akhirnya Dursa juga memperoleh bantuan sesuai gilirannya. Pada mulanya Pak Hartono berusaha untuk mengajak berdialog agar masalahnya tidak membesar. Ia berusaha memberikan sosialisasi dan transparansi terkait bantuan yang diberikan pada masyarakat. Deskripsi ini juga menggambarkan bahwa dalam satu arena pun besar kemungkinan terjadi konflik. Selain itu, hal ini menjadi representasi bahwa apa yang digagas oleh negara (termasuk di dalamnya birokrat desa) menjadi berbeda ketika diaplikasikan dalam praktik bermasyarakat. Selanjutnya saya akan menunjukkan kompleksitas gagasan dan praktik yang heterogen dalam masyarakat Desa Karangwuni.

\section{Dinamika Isolasi dalam Dua Perspektif}

Migdal telah menyebutkan bahwa negara yang sesungguhnya dibentuk oleh dua elemen, yaitu image dan praktik di mana kedua-nya bisa saja tumpang tindih dan menguatkan, atau justru kontradiktif dan saling merusak (Migdal, 
2004). Sekalipun berbagai kebijakan dan aturan telah dibuat dengan berbagai pertimbangan, ketika dipraktikkan bisa saja berbeda. Oleh karena itu, dalam upaya memperoleh gambaran yang holistik terkait relasi antara negara dan masyarakat penting untuk memperhatikan tataran praktik. Penekanan serupa juga pernah diungkapkan oleh Gupta (1995) bahwa penting untuk melihat negara dalam konteks praktik lokal karena pada tingkat inilah interaksi menjadi salah satu pengalaman orang tentang negara. Saya menggambarkan kompleksitas tersebut, dengan menampilkan kasus Sarmi (nama samaran) salah satu kerabat saya yang pernah diisolasi karena dinyatakan positif Covid-19.

Senin pagi pada tanggal 4 Januari 2021, saya pergi ke pasar tempat Sarmi berjualan. Ia jarang terlihat ataupun beraktivitas di rumah. Sarmi adalah tulang punggung keluarga, sehingga sebagian besar waktunya dihabiskan untuk bekerja di pasar; mulai dari kulakan (belanja untuk stok barang) serta memperjualbelikan dagangannya. Ia hanya menghabiskan waktu di rumahnya sekitar tiga jam untuk beristirahat sehingga ia tidak banyak berinteraksi dengan anggota keluarganya sendiri maupun tetangga sekitarnya.

Pada waktu itu, Sarmi sungguh kaget karena tiba-tiba bapak kepala RW mendatanginya dan menyuruhnya libur berdagang dan segera menjalankan isolasi. Hal itu karena ibunya dinyatakan positif Covid-19. Ibu Sarmi memang sudah sering sakit-sakitan. Ia sudah dirawat selama satu minggu di rumah sakit, tetapi setelah pulang dari rumah sakit dan dilakukan tes swab, hasilnya positif. Alhasil seluruh anggota keluarga yang dianggap sering berinteraksi, harus diisolasi secara mandiri. Lama isolasi mandiri yaitu sekitar 10 hingga 14 hari sesuai dengan ketentuan protokol kesehatan.

Hal yang membuat Sarmi geram adalah karena hasil swab menunjukkan bahwa ia negatif Covid-19, tetapi Pak RW dan perangkat desa yang lain bersikukuh untuk mengisolasi seluruh anggota keluarga dari warga yang terinfeksi. Saya dapat melihat bagaimana ekspresi marah Sarmi ketika menceritakan pengalaman isolasinya. Ia berbicara dengan menggebu-gebu, bola matanya membesar, dan gestur tubuhnya menunjukkan kejengkelan yang seolah tiada habisnya. Ia merasa bahwa jajaran pemerintah desa kurang bertanggung jawab, tidak terkecuali bidan desa. Selama diisolasi di rumah, ia hanya diberi beras dua kilogram sekali seminggu dan sayuran mentah setiap harinya. Tidak ada obat-obatan maupun vitamin yang disediakan untuknya.

Selepas 14 hari berlalu, Sarmi kesal karena meski diberi izin oleh kepala desa untuk mengakhiri isolasi, tidak ada pelepasan dari ketua RW maupun bidan desa. Apa yang tampak di sini adalah kurangnya koordinasi dari perangkat desa dalam menangani masyarakat yang terinfeksi beserta anggota keluarganya. Ia berharap agar ketua RW yang dari awal menahannya mau menunjukkan empatinya. Ia berharap ketua RW menyampaikan padanya, "Buk menawi karantina sampun selesai nek menawi ajeng golek sandang pangan jenengan pun bebas" (Bu, waktu karantinanya sudah selesai jika ingin mencari rezeki lagi sudah dipersilakan). Namun sayangnya, kalimat itu tidak pernah diucapkan ketua RW pada Sarmi.

Sarmi bahkan tidak segan membandingkan pengalamannya tersebut dengan pengalaman isolasi temannya yang merupakan warga desa lain, yaitu Desa Ngombakan. Ia menceritakan bahwa ketika temannya dinyatakan positif, pemerintah desanya langsung menyuplai kebutuhan pangan dalam jumlah yang banyak, misalnya saja beras empat kuintal dan mie satu kardus. Ia juga menyebutkan ketika temannya tersebut diisolasi, temannya tidak perlu mencemaskan apa pun karena bantuan yang diberikan melebihi kemampuannya dalam memenuhi kebutuhan sehari-hari. Sarmi pun dibuat semakin cemburu karena temannya tersebut juga disediakan vitamin dari bidan desa. Image negara yang membekas dalam benak Sarmi hingga saat ini tidak lain adalah kurangnya tanggung jawab dan koordinasi antarperangkat desa dalam menangani kasus Covid-19. Image tersebut terbentuk melalui 
praktik pemberian bantuan oleh pemerintah desa kepada Sarmi.

Saya akan memaparkan perspektif lain dari bidan desa yang turut memperkaya image negara. Di tengah gerimis malam hari, 5 Januari 2021, saya mengunjungi puskesmas untuk bertemu Bidan Dhika, bidan di Desa Karangwuni. Saya cukup kesulitan menemukan waktu yang cocok untuk bertemu dengannya karena $\mathrm{Bu}$ Dhika disibukkan dengan tugas mengontrol kesehatan di masyarakat.

Bu Dhika pun menyebutkan bahwa puskesmas sebenarnya tidak memberikan bantuan dalam bentuk materi, tetapi bantuan yang diberikan puskesmas cenderung berbentuk upaya promotif atau penyuluhan pada masyarakat. Bidan desa selaku perangkat di lini terbawah biasanya hanya memberikan upaya preventif (pencegahan) dan promotif saja. Sebab, semua pendanaan diatur oleh pemerintah desa. Pada tahun 2020, ada dana yang sengaja dialihkan untuk menangani Covid-19 sehubungan dengan bencana alam, wabah, dan sebagainya. Bahkan dana untuk kesehatan yang tadinya untuk kegiatan lansia dialihkan untuk pembelian vitamin karena kegiatan lansia terpaksa dihentikan semasa pandemi.

Menurut penilaian Bu Dhika, baik masyarakat maupun perangkat Desa Karangwuni terbilang cukup cekatan karena di awal pandemi ada kegiatan pembagian sabun dan masker ke seluruh rumah warga secara gratis. Ada pula penempatan sarana cuci tangan dan dilengkapi dengan MMT yang berisikan informasi himbauan untuk memenuhi protokol kesehatan. Birokrat desa berusaha melakukan berbagai upaya untuk memutus rantai penyebaran Covid-19. Mereka mencoba memanfaatkan berbagai sumber daya dan media dalam menyukseskan program tersebut. Upaya ini juga dapat dikategorikan sebagai perjuangan birokrat untuk mengendalikan desa sebagai arena dengan mengontrol sumber daya yang ada, walaupun pergulatan maupun konflik dalam masyarakat menjadi sesuatu yang tidak dapat dihindari.

$\mathrm{Bu}$ Dhika pun memberikan perspektif baru terkait kasus Sarmi yang menimbulkan kesalahpahaman. Kasus Sarmi tergolong sebagai kasus keluarga pertama yang terinfeksi Covid-19 di desa Karangwuni. Di dalam kasus tersebut, memang harus diakui bahwa pemerintah desa maupun pemerintah pusat masih meraba-raba sistem penanganan masyarakat terinfeksi Covid-19 yang efektif dan efisien. Pada saat itu sistem swab masih belum terpadu dan ada keterbatasan alat. Pada waktu itu sebenarnya hasil tes swab Sarmi belum keluar, tetapi ia sudah diperbolehkan mengakhiri isolasi oleh bidan karena masa inkubasi virus sudah dilewati. Hal ini disesuaikan dengan SOP (Standard Operating Procedure).

\section{Minim Evaluasi: Birokrat Desa Pasang Badan}

Di dalam menjalankan program dibutuhkan evaluasi untuk meningkatkan performa sistem yang diterapkan. Pemerintah desa sendiri belum melakukan evaluasi secara formal karena belum mendapatkan arahan dari pemerintah kabupaten maupun pemerintah pusat. Hal ini yang juga dikritisi oleh Pak Hartono yaitu dalam hal penerapan program dan praktik dibebankan pada pemerintah desa. Padahal tidak semua pemerintah desa mau peduli dengan masyarakat terdampak maupun masyarakat yang terinfeksi. Terkait dengan hal tersebut, bidan Desa Karangwuni menyatakan bahwa sebenarnya evaluasi terus dilakukan setiap ada koordinasi. Misal, setiap bersinggungan dengan kepala RT/RW dalam menyalurkan bantuan dan penyuluhan SOP pada masyarakat; sedangkan dalam praktik pemberian bantuan ada beberapa kendala yang harus dihadapi oleh birokrat desa. Bu Dhika selaku petugas kesehatan yang dalam kesehariannya berinteraksi langsung dengan masyarakat menyatakan beberapa keluh kesah, sebagai berikut:

“...Tapi sekarang kan ada media sosial, jadi kebanyakan masyarakat lebih percaya pada media sosial yang mengandung banyak hoaks. Kita sebagai tenaga kesehatan tidak kurang-kurang untuk menghimbau masyarakat untuk mematuhi protokol kesehatan. 
Kendala yang kita alami ialah tempuk (bertemu) dengan masyarakat itu. Dari kita yang di-eman-eman (disayang-sayangkan) masyarakat, namun mereka sering kali merasa bahwa aturan tersebut mengekang mereka. Padahal yang membuat aturan tersebut bukan pemerintah desa, bukan saya, tapi pemerintah pusat. Kita yang di bawah hanya berusaha menyampaikan informasi dari atas." (Wawancara dengan Bu Dhika, Bidan Desa Karangwuni, 05 Januari 2021)

Selain itu, dalam mengambil langkah penanganan masyarakat yang terinfeksi Covid-19, $\mathrm{Bu}$ Dhika tidak dapat hanya menunggu instruksi dari dinas kesehatan. Sebab, apa yang dibutuhkan adalah penanganan yang cepat. Bu Dhika pun memanfaatkan berbagai informasi yang ia coba kumpulkan sebisa mungkin. Langkah lanjutan yang dapat ia lakukan adalah dengan menghubungkan kebutuhan masyarakat dengan rumah sakit maupun dinas kesehatan. Bahkan ia dengan tegas menyampaikan bahwa dalam praktiknya tidak bisa menerapkan satu kontrol saja. Hal ini menunjukkan bahwa $i$ mage negara yang tidak koheren bisa dibuktikan ketika kita melihat praktik.

\section{Simpulan}

Pandemi Covid-19 berdampak pada seluruh sektor dalam kehidupan masyarakat, tidak terkecuali masyarakat desa. Di dalam mengatasi krisis selama pandemi, negara berusaha hadir dengan memberi bantuan pada masyarakat. Berbagai upaya penanganan dilakukan lewat kebijakan beserta implementasinya. Melalui upaya ini, negara berusaha memenuhi ruang dan mengukuhkan dominasinya pada masyarakat. Hal ini berkaitan dengan pembentukan image negara yang koheren. Namun, ketika melihat relasi negara dengan masyarakat, kita tidak dapat berfokus pada dimensi image semata.

Migdal menyuguhkan kerangka image dan praktik dalam melihat negara yang sesungguhnya. Lewat deskripsi penerapan kebijakan dan penyaluran bantuan di Desa Karangwuni semasa pandemi maka diperoleh gambaran bahwa tataran image dan praktik tidaklah selalu koheren. Image utuh negara pun dibedah kembali dengan memperhatikan bagaimana pemerintah desa dan masyarakat memperjuangkan dominasi dalam arena desa mereka. Berbagai aturan yang dapat dikatakan bertentangan dengan negara tetap disusun dengan melihat konteks dan kontrol sumber daya lokal. Hal ini menunjukkan bahwa dalam praktiknya, negara bukanlah satu-satunya otoritas yang mampu membuat aturan. Dominasi total negara pada masyarakat pun hanya utopia belaka. Relasi yang tercipta antara negara dan masyarakat Desa Karangwuni ialah saling tarik-menarik.

\section{Daftar Pustaka}

Aziz, N. L., Zuhro, R. S., Maulana, Y., dan Rahmiati, D. (2021). Pola Relasi Pusat dan Daerah Era Pandemi Covid-19. Jurnal Penelitian Politik, 18(1), 77-94. https://doi.org/ https://doi.org/10.14203/jpp.v18i1.967

Bayuni, E. (17 Maret 2020). Covid-19 Lockdown? It's Not The Economy, It's People's Health and Lives. The Jakarta Post. Dikutip dari https://www.thejakartapost.com/academia/2020/03/17/covid-19-lockdown-itsnot-the-economy-stupid-its-peoples-healthand-lives.html

Buzard, J. (2003). On Auto Ethnographic Authority. The Yale Journal of Criticism, 16(1), 61-91.

Creswell, J. W. (2007). Qualitative Inquiry and Research Design: Choosing Among Five Approaches (2nd Ed.). California: Sage Publication.

Ekklesia, J. M. (2021). Relasi Sosial Warga Negara terhadap Pemerintah: Fenomena Ketidakpatuhan Selama Pandemi dalam Teori Sosiologi dan Nilai Kristiani. FGD Sospol Perkantas Jatim 24 Juli 2021, 1-17.

Funay, Y. E. N. (2020). Indonesia dalam Pusaran Masa Pandemi: Strategi So- lidaritas Sosial Berbasis Nilai Tradisi Lokal. JSAI: Jurnal Sosiologi Agama Indonesia, 1(2), 107-120. https://doi.org/10.22373/jsai.v1i2.509

Gupta, A. (1995). Blurred Boundaries: The Discourse of Corruption, The Culture of Politics, and The Imagined State. American Echologist, 22(2), 375-402. https://doi.org/10.1093/ acprof:oso/9780199685011.003.0013

Harirah, Z., dan Rizaldi, A. (2020). Merespon 
Nalar Kebijakan Negara dalam Menangani Interdisiplin, 24(1), 3-20. Panemi Covid 19 di Indonesia. Jurnal Ekonomi Dan Kebijakan Publik Indonesia, 7(1), 36-53. https://doi.org/10.24815/ekapi.v7i1.17370

Karyono, K., Rohadin, R., dan Indriyani, D. (2020). Penanganan dan Pencegahan Pandemi Wabah Virus Corona (Covid-19) Kabupaten Indramayu. Jurnal Kolaborasi Resolusi Konflik, 2(2), 164-173. https://doi. org/10.24198/jkrk.v2i2.29127

Kerkvliet, B. J. T. (2018). An Approach for Analysing State-Society Relations in Vietnam. Sojourn: Journal of Social Issues in Southeast Asia, 33(S), S156-198.

Laszczkowski, M. (2015). Introduction: Affective States-Entanglements, Suspensions, Suspicions. Social Analysis, 59(4), 1-14. https:// doi.org/10.3167/sa.2015.590401

Migdal, J. S. (2004). State in Society: Studying How State and Societies Transform and Constitute One Another. Cambridge: Cambridge University Press.

Mulyadi, M. (2020). Partisipasi Ma-syarakat dalam Penanganan Penyebaran Covid-19. Bidang Kesejahteraan Sosial Info Singkat: Kajian Singkat terhadap Isu Aktual dan Strategis, 12(8), 13-18.

Pribadi, S. (2020). Revitalisasi Pos Kamling Berbasis Komunitas di Masa Pandemi Covid-19. Jurnal Keamanan Nasional, 6(2), 304-321. https://doi.org/19.1056/nejmoa2002032

Rachman, F., dan Fitra, I. (2020). Kewarganegaraan dan Kesehatan: Partisipasi Warga dalam Penanganan Pandemi Covid-19 di Indonesia. Jurnal Ilmiah Pendidikan Pancasila dan Kewarganegaraan, 5(2), 289-303. http://dx. doi.org/10.17977/um019v5i2p289-303

Ristyawati, A. (2020). Efektifitas Kebijakan Pembatasan Sosial Berskala Besar dalam Masa Pandemi Corona Virus 2019 oleh Pemerintah Sesuai Amanat UUD NKRI Tahun 1945. Administrative Law and Governance Journal, 3(2), 240-249.

Saraswati, P. S. (2020). Kebijakan Hukum terhadap Penanganan Pandemi Covid-19 di Indonesia. Kertha Wicaksana, 14(2), 147-152. https://doi.org/10.22225/kw.14.2.1923.147152

Scott, J. C. (1998). Seeing Like A State: How Certain Schemes to Improve The Human Condition Have Failed. New Haven: Yale University Press.

Therik, W. M. A. (2015). Relasi Negara dan Masyarakat di Rote. Jurnal Studi Pembangunan 